\title{
Analisis Sistem Administrasi di Badan Usaha Milik Desa Wibawa Mukti Desa Sekarwangi Kabupaten Sumedang
}

\section{Analysis of Administrative System in Badan Usaha Milik Desa Wibawa Mukti Village Sekarwangi of Sumedang District}

\author{
Ayu Cahyani*, Adi Supriatna, M. Siddiq Somantri, Teti Yuningsih, \& Arip Rahman \\ Sudrajat \\ Ilmu Administrasi Negara, Sekolah Tinggi Administrasi Negara Sebelas April Sumedang, \\ Indonesia
}

Diterima: Agustus 2019; Disetujui: Desember 2019; Dipublish: Desember 2019

${ }^{*}$ Coresponding Email: avucahvani65@gmail.com

\begin{abstract}
Abstrak
Tujuan penulisan penelitian ini adalah untuk menganalisis mengenai sistem pengadministrasian yang dilakukan di Badan Usaha Milik Desa di Desa sekarwangi Metode yang digunakan dalam penelitian ini adalah analisis deskriptif dengan melakukan observasi terlebih dahulu kepada objek penelitian yang bersangkutan dengan focus observasi mengenai sistem pengadministrasian yang dilakukan oleh pengurus Badan Usaha Milik Desa. Lokasi penelitian adalah di Desa Sekarwangi Kecamatan Buahdua Kabupaten Sumedang. Dalam melakukan observasi, terdapat kegiatan wawancara dengan narasumber sebanyak tiga orang yang merupakan pegawai Badan Usaha Milik Desa. Berdasarkan hasil observasi dan wawancara, hasil penelitian menunjukkan bahwa kegiatan sistem pengadministrasian di Badan Usaha Milik Desa ini masih rendah. Hal ini disebabkan oleh beberapa faktor diantaranya masih kurangnya tenaga kerja, kurangnya sarana dan prsarana kantor, rendahnya keterampilan pegawai serta sumber daya modal yang masih minim. Penelitian ini berkesimpulan bahwa di dalam kepengurusan Badan Usaha Milik Desa di Desa sekarwangi masih terdapat kegiatan administrasi yang belum optimal dan belum berjalan dengan baik dikarenakan danya factor-faktor dalam system administrasi yang belum terpenuhi baik secara kepegawaian maupun secara permodalan.
\end{abstract}

Kata Kunci: Sistem, Administrasi, Badan Usaha Milik Desa

\begin{abstract}
The purpose of writing this research is to analyze the administration system which is carried out in the Village-Owned Enterprises in Sekarwangi Village. The method used in this research is descriptive analysis by first observing the relevant research object with a focus on observing the administration system which is carried out by the board administrator Village Owned Business. The location of the research is Sekarwangi Village, Buahdua District, Sumedang Regency. In conducting observations, there were three interviews with resource persons who were employees of the Village Owned Enterprises. Based on observations and interviews, the results showed that the administration system activities in the VillageOwned Enterprises were still low. This is caused by several factors including the lack of labor, lack of facilities and office infrastructure, low employee skills and minimal capital resources. This study concludes that in the management of Village-Owned Enterprises in Sekarwangi Village there are administrative activities that are not optimal and have not run well due to funding factors in the administrative system that have not been fulfilled either in personnel or in capital.
\end{abstract}

Keywords: System, Administration, Badan Usaha Milik Desa

How to Cite: Cahyani, A., Supriatna, A., Somantri, M.S., Yuningsih, T., \& Rahman A. (2019). Analisis Sistem Administrasi di Badan UsahaMilik Desa Wibawa Mukti Desa Sekarwangi Kabupaten Sumedang. Journal of Education, Humaniora and Social Sciences (JEHSS). 2 (2): 203-212. 


\section{PENDAHULUAN}

Dalam menjalankan kehidupan bernegara semua masyarakat memilki peranan masing-masing untuk menciptakan kehidupan bernegara yang tertib dan aman serta selaras dengan aturan sistem pemerintahan yang dianut oleh suatu Negara. Sistem pemeritahan tersebut dijalankan oleh aparat Negara yang disebut dengan Pemerintah yang bertanggung jawab atas segala tugas Negara untuk melayani seluruh warga Negara. Pemerintahan tersebut dibagi menjadi dua yaitu pemerinah pusat dan pemerintah daerah. Pemerintah pusat yaitu pemerintah yang tugas dan wewenangnya yaitu bekerja pada pusat pemerintahan Negara. Sedangkan pemerintah daerah yaitu pemerintah yang tugas dan wewenangnya berada pada pemerintahan daerah otonom masing-masing baik itu pemerintah daerah Provinsi, Kabupaten/Kota, Kecamanatan ataupun Kelurahan/Desa.

Dalam pemerintahan desa, terdapat badan usaha yang kewenangannya berada dibawah pemerintahan Desa. Badan usaha milik desa atau yang familiar dengan istilah BUMDES merupakan usaha desa yang dikelola oleh pemerintah dan berbadan hukum yang bertujuan untuk meningkatkan pendapatan desa, mengangkat potensi desa dan meningkatkan pendapatan masyarakat terkait dengan jalannya usaha bumdes tersebut. Pemerintah desa dapat mendirikan badan usaha milik desa sesuai dengan kebutuhan dan potensi desa. Pembentukan badan usaha milik desa ditetapkan oleh peraturan desa serta kepengurusan bumdes terdiri dari pemerintah desa dan masyarakat sekitar desa. Permodalan badan usaha milik desa berasal dari pemerintah desa, tabungan masyarakat, bantuan pemerintah, pemerintah Provinsi dan pemerintah Kabupaten/Kota, pinjaman, atau penyertaan modal pihak lain atau kerja sama bagi hasil atas dasar saling menguntungkan.

Begitu pula yang dijalankan oleh Bumdes Wibawa Mukti Desa Sekarwangi Kecamatan Buahdua Kabupaten Sumedang yang didirikan dua tahun yang lalu sebagai badan usaha untuk mendukung produk unggulan Desa Sekarwangi. Berdasarkan pengamatan yang telah dilakukan, kami menemukan beberapa kendala yang menghambat berjalannya Bumdes Wibawa Mukti Desa Sekarwangi Kecamatan Buahdua Kabupaten Sumedang dengan indikasi masalah dantaranya; a. masih kurangnya pegawai yang bekerja dalam badan usaha milik desa di Desa sekarwangi sehingga kurangnya inovasi dari organisasi tersebut; b. kurangnya pengetahuan dan keterampilan dalam 
sistem pengadministrasian mengenai badan usaha milik desa, seperti pembukuan penjualan, pembukuan perhitungan lama, tidak adanya struktur organisasi, dan laimlain; c. masih kurangnya kerjasama yang terjalin dengan pihak masyarakat pemilik industri rumahan yang memproduksi produk unggulan sehingga penjualan produk unggulan di badan usaha milik desa masih sanga rendah; d. baru didirikan selama dua tahun yang lalu dan berjalan satu tahun yang lalu sehingga pengerjaannya belum maksimal.

Hal tersebut menjadi fokus perhatian penulis sehingga penulis tertarik untuk menganalis lebih dalam mengenai sistem administrasi di badan usaha milik desa di Dsa Sekarwangi agar dapat menemukan solisi dan beberapa faktor penghambat rendahnya sistem pengadministrasian dalam organisasi tersebut.

Telah ada beberapa penelitian yang mengkaji tentang sistem administrasi pada badan usaha milik desa, diantanya sebagai berikut. Eriswanto (2017) dengan judul pengelolaan sistem administrasi bagi BUMDes di Desa Sukaraja. Penelitian ini dilakukan degan metode deskriftif dengan pendekatan kualitatif, teknik peneliti dengan menggunakan teknik pengumpulan data dengan wawancara, observasi dan dokumentasi sedangkat analisis data menggunakan reduksi data, display data dan penarikan kesimpulan. Hasil penelitian menunjukan bahwa manajemen SDM belum dikelola dengan baik, adminisrasi yang dijalankan masih minim dan pengurus bumdes belum memiliki jejaring yang luas sehingga dapat disimpulkan pengelolaan administrasi masih sederhana.

Amri (2015) dengan judul Evaluasi program badan usaha milik desa (Bumdes). Penelitian ini dilakukan dengan menggunakan teknik snowball sampling. Penelitian ini merupakan penelitian kualitatif. Teknik pengumpulan data dalah wawancara mendalam. Data dianalisis dengan metode deskriptif kualitatif. Dari hasil penelitian menunjukkan bahwa evaluasi pelaksanaan program BUMDes secara keseluruhan sudah terlaksana dengan baik, manun belum maksimal. Dampak yang kurang baik dari program ini adalah biaya langsung. Sementara pada indikator lain seperti sasaran kebijakan, diluar sasaran kebijakan, kondisi sekarang dan akan datang dan biaya langsung sudah terlaksana dengan baik.

Fajarwati (2016) dengan judul Implementasi program badan usaha milik desa (BUMDes) di Desa Pangadangan Kecamatan Pagedangan Kabupaten Tangerang. Metode 
yang digunakan kualitatif deskriptif. Teknik pengumpulan data yang digunakan adalah wawancara, bservasi, studi pustaka dan dokumentasi. Analisis data yang digunakan adalah model Prasetya Irawan. Hasil penelitian menunjukkan bahwa implementasi program BUMDes secara umum sudah berjalan dengan baik. Hal ini dapat dilihat berdasarkan berjalannya program-program BUMDes secara baik. Meski dalam segi perencanaan keuangan dan program belum terkelola dengan baik sehingga program BUMDes belum sepenuhnya berjalan optimal karena ada beberapa yang harus diperbaiki seperti kurangnya sumber daya manusia dan finalsial serta lemahnya sosialisasi dan minimnya koordinasi.

Anggraeni (2016) dengan judul Peran badan usaha milik desa (Bumdes) pada ksejahteraan masyarakat pedesaan studi pada bumdes di Gunung Kidul, Yogyakarta. Penelitian ini bertujuan untuk menggali dampak keberadaan badan usaha milik desa pada kesejahteraan masyarakat. Penelitian ini menggunakan metode Community Based Research, dimana penelitian dilakukan dalam beberap tahap, yaitu: in-depth interview dengan partisipan yang menjadi aktor kunci dalam BUMDes, tahap selanjutnya melakukan diskusi kelompok berdasarkan kelompok kepentingan yang ada di desa tersebut, dan pada tahap akhir dilakukan Focus Group Discussion dimana diskusi dilakukan oleh pelbagai pihak yang berkepentingan. Hal ini dilakukan juga untuk melakukan konfirmasi atas hasil temuan pada tahap sebelumnya. Hasil dari penelitian ini menunjukkan keberadaan BUMDes tidak dipungkiri membawa perubahan di bidang ekonomi dan sosial. Keberadaan BUMDes tidak membawa manfaat signifikan bagi peningkatan kesejahteraan warga secara langsung, permasalahan yang muncul terkait BUMDes adalah akses masyarakat terhadap air dan akses masyarakat untuk mendapatkan pekerjaan di BUMDes.

\section{METODE PENELITIAN}

Dalam melakukan penelitian ini, penulis menggunakan metode penelitian kualitatif untuk mengkaji lebih dalam hal-hal yang berkaitan dengan sistem administrasi bumdes. Menurut (Gunawan, 2013) mmmentode penelitian kualitatif adalah jenis penelitian yang jenis ytemuan-temuannya tidak diperoleh melalui prosedur statistic atau bentuk hitungan lainnya. Metode kualitatif beruaha memahami dan menafsirkan makna suatu interaksi tingkah laku manusia dalam situasi tertentu menurut perspektif peneliti 
terdahulu. Selanjutnya (Gunawan, 2013) menyebutkan bahwa penelitian yang menggunakan penelitian kualitatif bertujuan untuk memahami objek yang diteliti secara mendalam. Berdasarkan penjelasan tersebut, kami menggunakan jenis penelitian kualitatif dengan pendekatan deskriptif. Objek penelitian adalah Kantor Sekretariat Badan Usaha Milik Desa Wibawa Mukti Desa Sekarwangi beserta seluruh unsur yang terkait.

Variabel yang diuji yaitu sistem administrasi dengan teknik pengumpulan data yang digunakan yaitu observasi berupa pengamatan secara langsung terhadap objek yang diteliti yaitu kantor sekretariat badan usaha milik desa di desa Sekarwangi meliputi pengamatan mengenai fasilitas yang tersedia, pegawai yang sedang mengerjakan tugasnya, serta pengamatan mengenai peralatan kantor yang dinilai masih belum lengkap. Teknik pengumpulan data selanjutnya yaitu wawancara, penulis menyiapkan beberapa pertanyaan mengenai sisitem administrasi di badan usaha milik desa tersebut dengan narasumber yang diwawancarai yaitu ketua badan usaha milik desa di Desa Sekarwangi.

\section{HASIL DAN PEMBAHASAN}

Berdasarkan pengamatan yang telah dilakukan, terdapat beberapa kendala terkait sistem pengadministrasian di badan usaha milik desa di Desa Sekarwangi. Diketahui bahwa sistem pengadministrasian di badan usaha milik desa tersebut masih dibawah standard dan belum sesuai dengan yang seharusnya. Bersasarkan indikasi masalah yang ada, kami berpacu pada teori administrasi yang dapat dijadikan sebagai tolak ukur kualitas sistem administrasi di badan usaha milik desa di Desa Sekarwangi, yaitu sebagai berkut:

Administrasi dalam pengertian yang sempit yaitu kegiatan ketatausahaan yang intinya adalah kegiatan rutin catat-mencatat, mendokumnetasikan kegiatan, sebemnyelenggarakan surat-menyurat dengan segala aspeknya serta mempersiapkan laporan (Abi, 2014). Selanjutnya Sondang P. Siagian (2003) menyebutkan bahwa dministrasi adalah keseluruhan proses kerjasama antara dua orang atau lebih yang didasarkan atas rasionalitas tertentu untuk mencapai tujuan yang telah ditentukan sebelumnya. 
Anggara (2012) menyebutkan bahwa dalam prosesnya administrasi memiliki unsur-unsur yang terkait antara satu dan lainnya. Jika salah satu unsurnya tidak ada, proses administrasi akan pincang. Unsur-unsur tersebut meliputi sebgai berikut. 1). Organisasi, yaitu wadah bagi segenapkegiatan usaha kerja sama. 2). Manajemen, yaitu kegiatan menggerakkan sekelompok orang dan mengerahkan fasilitas kerja, seperti perencanaan, pembuatan keputusan, pembimbigan, pengoordinasian, pengawasan (control), penyempurnaan dan perbaikan tata struktur dan taat kerja. 3). Komunikasi, yitu penyampaian berita dan pemindahan pikiran seseorang kepada yang lainnya dalam rangka terwujudnya kerja sama. 4). Kepegawaian, yaitu pengaturan dan pengurusan pegawai atau karyawan yang diperlukan. 5). Keuangan, yaitu pengelolaan segi-segi pembiayaan dan pertanggungjawaban keuangan. 6). Perbekalan, yaitu perencanaan, pengadaan, dan pengaturan pemakaian barang-barang keperluan kerja. 7). Tata usaha, yaitu penghimpunan, pencatatan, pengolahan, pengiriman, dan penyimpanan berbagai keterangan yang diperlukan. 8). Hubungan masyarakat, yaitu perwujudan hubungan yang baik dan dukungan dari lingkungan masyarakat terhadap usaha kerja sama.

Berdasarkan teori diatas, penulis mengaitkan fenomena yang terjadi di lapangan dengan unsur-unsur administrasi tersebut sebagai berikut: pertama adalah faktor rendahnya sistem administrasi di badan usaha milik desa di Desa Sekarwangi yang pertama yaitu menyangkut kurangnya pegawai, yaitu termasuk dalam unsur administrasi mengenai kepegawaian. Badan usaha milik desa di Desa Sekarwangi dinilai kurang aktif dalam melakukan perekrutan pegawai sehingga organisasi tersebut tidak mengalami penambahan pegawai. berdasarkan hasil wawancara, pihak badan usaha milik desa belum melakukan perekrutan pegawai dengan alasan masih banyak pertimbangan yang harus dipikirkan terlebih dahulu seperti bagaimana melakukan penggajian pegawai baru. Selain itu, narasumber menuturkan bahwa dari pihak masyarakat pun terlihat bahwa tidak sedikit masyarakat yang merasa kurangberminat untuk bergabung menjadi pegawai bumdes tersebut.

Proses penyediaan tenaga kerja merupakan upaya untuk mendapatkan dan menghimpun, serta menyediakan tenaga kerja yang mempunyai kualitas dan dapat bekerja secara efisien. Fathoni (2009).

Berdasarkan pengertian diatas, penulis berpacu pada proses manajemen kinerja yang ditulis oleh Burtonshaw-Gunn (2011) yaitu sebagai berikut: 


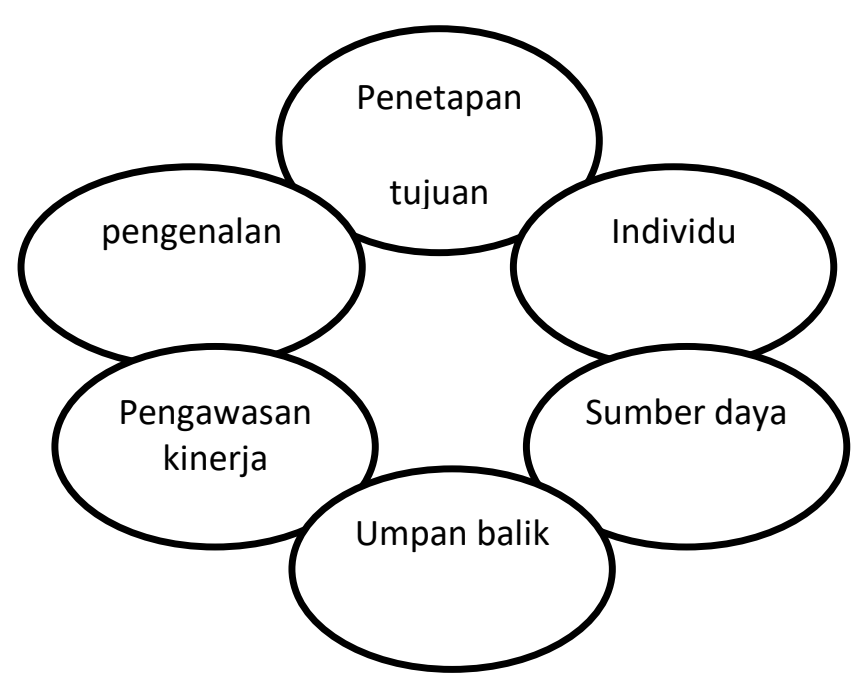

Berdasarkan hal di atas, bahwa dalam mencapai manajemen kinerja, bumdes di Desa Sekarwangi pada umumnya belum maksimal karena salah satu unsur yang paling penting yaitu sumber daya, dan dalam halnya sumber daya manusia masih sangat kurang, serta sumber daya yang ada pun masih kurang berkompeten. Di Bumdes Wibawa Mukti ini pegawai yang aktif mengelola bumdes hanya ketua, sekretaris dan bendahara saja, sedangkan beberapa pegawai lainnya tidak ikut dalam kepengurusan bumdes. Ketua bumdes dinilai tidak efektif dalam memaksimalkan sumber daya manusia sehingga sumber daya manusia yang tidak memberikan kinerjanya dibiarkan saja dan tidak ada tindakan untuk mengganti dengan sumber daya manusia yang kebih kompeten.

Selanjutnya untuk faktor yang kedua yaitu kurangnya pengetahuan mengenai pengadministrasian dalam menjalankan bumdes, pegawai tidak mengerti cara pencatatan keuangan dan pencatatan transaksi penjualan. Hal tersebut berkaitan dengan teori administrasi secara sempit yang mencangkup pencatatan dalam suatu organisasi. Secara etimologi, administrasi berasalah dari kata ad dan ministrate yang berarti melayani, membantu, memenuhi, melaksanakan, menerapkan, mengendalikan, menyelenggarakan, mengarahkan, menghasilgunakan, mengelola, mengatur, mengurus, mengusahakan, mendayagunakan. Khaerul Umam, (2014)

Berdasarkan hal tersebut dan dikaitkan dengan data dilapangan, pegawai bumdes belum dapat menjalankan kegatan administrasi yang baik dan efektif dan sesuai dengan kaidah yang telah ditetapakn dalam proses administrasi. Berdasarkan hasil observasi penulis, pegawai bumdes masih melakukan pengadministrasian yaitu pencatatan keuangan yang masih manual, serta kemampuan pembuatan surat pun masih kurang dan sarana yang tidak mendukung seperti tidak adanya komputer yang tersedia sehingga pegawai harus menggunakan komputer milik pribadi untuk pembuatan surat. 
Faktor yang ketiga yaitu kurangnya kerjasama dengan masyarakat yang memiliki usaha rumahan berupa produk unggulan di Desa Sekarwangi. Berdasarka hasil wawancara, terdapat dua faktor dalam masalah kerjasama tersebut. Yang pertama yaitu kurangnya sosialisasi yang dilakukan oleh pegawai bumdes kepada masyarakat, pegawai tidak melakukan sosialisasi secara rutin dan efektif, dan hanya melakukan sosialisasi secara informal kepada sebagian pelaku usaha rumahan. Faktor yang kedua yaitu kurangnya partisipasi dari masyrakat pelaku usaha rumahan untuk mmasarkan produknya melalui bumdes karena masyarakat sudah memiliki sasaran usaha sendiri, selain itu terdapat beberapa masyarakat yang belum mengetahui informasi mengenai sistem kerjasama tersebut.

Faktor tersebut berkaitan dengan salah satu unsur administrasi yaitu manajemen. Manajemen adalah proses merencanakan, mengorganisasi, mengarahkan, dan mengendalikan kegiatan untuk mencapai tujuan organisasi secara efektif dan efisien dengan menggunakan sumber daya organisasi.

Gambar 1.1 berikut ini menunjukkan definisi dan pengertian manajemen yang dikaitkan dengan organisasi dan manager.

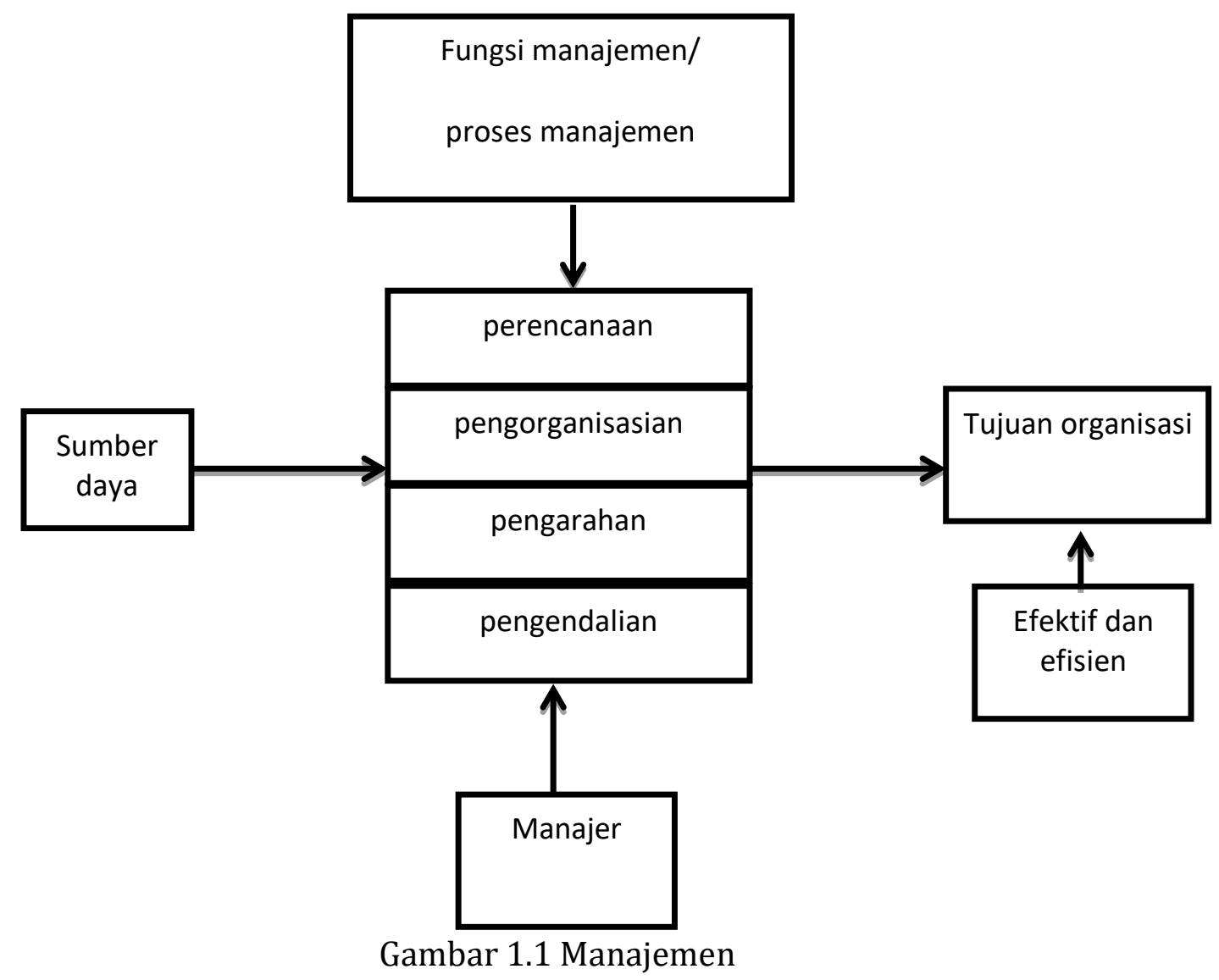

Berdasarkan hasil wawancara dan observasi pada objek penelitian, didapati bahwa kurangnya pengarahan dari betua bumdes sebagai pimpinan kepada bawahan untuk melakukan tugas manajemennya yaitu bekerja sama dengan warga sekitar yang 2त्रि http://mahesainstitute.web.id/ojs2/index.php/jehss 
berpotensi dapat meningkatkan kinerja bumdes melalui kerjasama penjualan produk unggulan yang diproduksi masing-masing warga. Pengurus bumbes kurang melakukan pembinaan dan penggerakkan terhadap pengusaha produk unggulan sehingga banyak pengusaha menjual produknya sendiri. Narasumber menuturkan bahwa kurangnya pembinaan tersebut memang menjadi kendala dalam menjalankan bumdes tersebut.

Dan faktor yang terakhir yaitu kurangnya modal dalam mengelola bumdes tersebut. Menurut narasumber, hal tersebut dikarenakan oleh kurangnya komunikasi dan sosialisasi dengan beberapa asyarakat yang berpotensi menjadi investor bumdes dan kurangnya koordinasi dengan pihak desa mengenai permodalan bumdes. Kurangnya modal tersebut menjadi salah satu faktor terbesar dalam menjalankan badan usaha milik desa tersebut karena menjadi penghambat faktor yang lain seperti pengadaan sarana prasarana, perekrutan pegawai, pelatihan pegawai agar lebih berkompeten yang jka terud ditingkatkan makan akan berpengaruh juga pada perbaikan sistem administrasi bumdes tersebut.

\section{SIMPULAN}

Dari pemaparan di atas, penulis dapat menyimpulkan bahwa sistem pengadministrasian di badan usaha milik desa di Desa Sekarwangi masih rendah da masih jauh jika dibandinkan dengan teori administrasi yan telah dipaparan dalam pembahasan. Rendahnya sistem administrasi tersebut dipengaruhi oleh beberapa faktor internal dan eksternal yang masih kurang endukung adanya bumdes tersebut. Setelah dikaitkan dengan teori administrasi, didapatkan kesimpulan bahwa yang menjadi faktor rendahnya sistem admnistrasi pada bumdes tersebut diantaranya mengenai perekrutan pegawai, sistem pencatatan yang masih dilakukan secara manual, rendahnya pengarahan yang dilakukan oleh opimpinan kepada baahan yang berkaitan dengan lingkup manajemen, dan yang terakhir yaitu sumber daya modal yan masih terbatas. Pihak bumdes dinilai masih rendah dalam menjalin kerjasama dengan beberapa orang yang dinilai berpotensi menjadi investor serta kurangnya koordinasidengan pihak desa sebagai pusat pemerintahan dalam lingkup Desa Sekarwangi tersebut. Dengan demikian, pegawai badan usaha milik desa di Desa Sekarwangi diharapkan dapat meningkatkan kemampuan dalam menjalakan sistem administrasi. 


\section{DAFTAR PUSTAKA}

Amri, K (2015). Evaluasi Program Badan Usaha MIlik Desa (BUMDES). Jurnal Administrasi Negara:13(3):295

Anggraeni, M.R.R.S. (2016). Peranan Badan Usaha Milik Desa (BUMDES) Pada Kesejahteraan Masyarakat PEedesaan Studi Pada Bumdes di Gunung Kidul, Yogyakarta.MODUS:28(2):155

Eriswanto, M \& Sudarma. (2017). Pengelolaan Sistem Administrasi Bagi BUMDes di Desa Sukaraja. Jurnal Penelitian dan Pengembangan Sains dan Teknologi:11(3):1-7.

Fajarwati, Y. (2016). Implementasi Program Badan Usaha Milik DEsa (BUMDes) di Desa Pagedangan Kecamatan Pagedangan Kabupaten Tangerang. Serang. Universitas Sultan Ageng Tritayasa.

Fathini, A. (2009). Organisasi dan manajemen sumber daya manusia. Jakarta: PT Rineka Cipta

Gunawan, I. 2013. Metode penelitian kualitatif. Jakarta: bumi aksara. Hlm. 1

Hanafi, M. (2016). Konsep Dasar dan Perkembangan Teori manajemen.

Rizki, M. (2019). Padang Administrasi dan Supervise Pendidikan.

Siagian, S.P. (2003). Filsafat Administrasi. Jakarta: Bumi Aksara.

Syahraji \& Irwan N., (2013). Sistem Administrasi Pelayanan E-KTP di Kecamatan Bebesen Kabupaten Aceh tengah, Jurnal Administrasi Publik Universitas Medan Area, 1 (1): 16-20

Umam, K. (2014). Manajemen Perkantoran. Bandung: Pustaka setia 